4.6 2-フェニルプロピオン酸エチル（II）のラセミ化

Iはエタノール溶媒中, 塩酸の存在下ではほとんどラセミ化し 的ったが，水酸化ナトリウムの存在下では比較的速やかにラセ

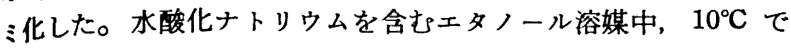
のIIのラミ化に対する経時変化を図6に示した。
(1962 年 4 月, 日本化学会第 15 年会 (一部) 講演)

本研究にあたり, 直径 $0.027 \mathrm{~mm}$ のニッケル線を引いて下さっ た東北大学名誉教授, 仙台精密研究所所長增本量先生ならびにラ ネー合金を提供下さった川上研究所に感謝申し上げます。

\title{
アセトニル型ラジカルによるグリシッド酸エステルの開環反応
}

（昭 和 40 年 2 月 15 日 受 理）

奥

彬* ・岡野正弥**. 庄野達哉*・小田良平*

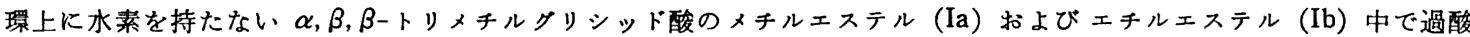
化ジ-tーブル (DTBP) を熱分解させ，その生成物を調べ，アセトニルラジカルのエポキシ環への攻撃に括ける二, 三の 特性について考察を行なった。反応生成物としてはIa からはアセトニルアセトン（II），アセトニルラシカル(X)とIa

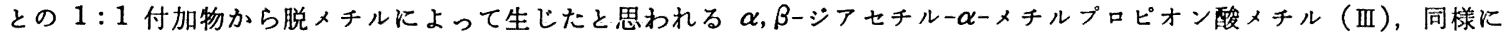

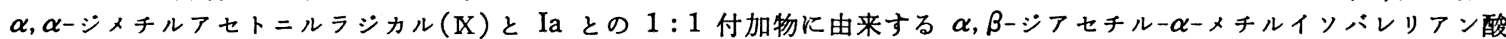
×チル $(\mathrm{N})$, さらに $1: 2$ 付加物に由来するエステル $(\mathrm{V})$ を単離し, また Ib からは X と Ib の $1: 1$ 付加物, $1: 2$ 付

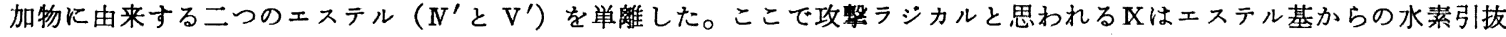
き, 脱アルデヒト，脱一酸化炭素，転位により生じたものと考えられ，Ia では水素引抜きがやや困難で，併行してアセ トンからXが生成したものと解釈される。またこのラジカル付加がェステルの $\alpha$-位環炭素上に起こっていることから， 遷移状態でのカルボニル基の関与が考えられる。
\end{abstract}

\section{1 緒 宝}

エポキシドの液相でのラジカル反応に関しては未だ研究報告が 少ないが，つぎの二つの反応様式が知られている。1.エポキシ環 上の水素引抜き反応1)（熱時では続いて生成エポキシラジカルの アシルメチル型ラジカルヘの転位を伴 $5^{2,3)}$ )。2. 環炭素へのラジ カル攻撃による付加開環反応 ${ }^{2,3)}$ 。1 の反応は線状エーテルで既 に良く知られており，興味深いのはむしろ 2 の付加開環反応であ る。これはエポキシドの炭素-酸素結合の 解離エネルギーが環の 歪のため低い(約 $50 \mathrm{kcal} \cdot \mathrm{mol}^{-1}$ 4) ) ことに由来するすので，炭素 一炭素二重結合と同様比較的容易にラジカル付加をうけるるのと 思われる。しかし一般のエポキシドに扎いては 2 の反応よりるさ らに容易な 1 の反応が同時に起こり, 付加開環反応の検討には適 当でなく, 環上に水素を持たないエポキシドを用いるのが望まし い。さらに炭素-炭素二重結合へのラジカル付加で共役性の基が 砶に影響を与えることが認められているのにかんがみ゙5，合成 の容易な点も考虑に入れ、トリメチルグリシッド酸エステル (Ia, Ib)を用いることにした。

* Akira OKU, Tatsuya SHONO, Ryohei ODA 京都大学工 学部合成化学教室 : 京都市左京区吉田.

** Masaya OKANO 京都大学化学研究所: 高梘市大学町.

1) (a) T. J. Wallace, R. J. Gritter, Tetrahedron 19, 657 (1963) ; (b ) C. Walling, P. S. Fredricks, J. Am. Chem. Soc. 84, 3326 (1962).

2) 网, 野, 小田, Bull. Chem. Soc. Japan 37, 570 (1964).

3) R. J. Gritter, T. J. Wallace, J. Org. Chem. 26, 282 (1961).

4) P. Gray, A. Williams, Chem. Revs. 59, 239 (1959).

5) M. Szwarc, R. Buckley, J. Am. Chem. Soc. 78, 5696 (1956).<smiles>[R]OC(=O)C1(C)OC1(C)C</smiles>

Ia $: \mathrm{R}=\mathrm{CH}_{3}$ Ib : $\mathrm{R}=\mathrm{C}_{2} \mathrm{H}_{5}$

\section{2 実 験 結 果}

la および Ib と過酸化ジー $t$-ブチル (DTBP) との反応は, エポ キシェステルを溶媒兼用で過剩に用い（過酸化物 $1 \mathrm{~mol}$ に対し $4 \mathrm{~mol}$ ) 両者の混合物を $140 \sim 142^{\circ} \mathrm{C} て ゙ 8$ 時間加熱し, その後反応 生成物中から蒸留で単離可能の生成物を分ちとり, それらの構造 決定と確認を行なった。DTBPは分解温度が適当でしか子分解生 成物にとくにイオン反応を有利にするすのがなく, 開始剤として 好都合であるが，他の中性開始剤アゾビスイソブチロニトリルは 水素引抜能が弱く，不適当である2)ことを著者らは前に実験的に 立証済みである。な和空実験として，Ia あるいは IbをDTBP の分解生成物であるアセトン, $t$-ブタノールと同一条件下で加熱 したが，何ら反応生成物は得られなかった。

Ia および Ib と DTBP の反応で得られた生成物を, それぞれ 表 1 ，表 2 によめて示した。

低沸点生成物は反応器からの流出ガスをドライアイスーメタノ 一ル浴で泠却液化させ，これを直接ガスクロマトグラフィーで分 析し表に示す組成比を得た。いずれの場合にもアセトン，tーブタ ノールが主成分であるが, Ib からはアセトアルデヒドを少量確 認した。一酸化炭素は前記ドライアイストラップを経て流出した ガスを五酸化ヨウ素管に導き酸化して炭酸ガスとして確認した。

高沸点生成物は次のようにして確認した。まずIIは回収 Ia の 留分中に含まれ，2,4-ジニトロフェニルヒドラジンでヒドラジン

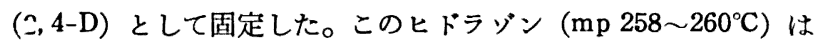
僄品アセトニルアセトンのそれ (mp 263〜264 $\left.{ }^{\circ} \mathrm{C}\right)$ と混融しても 融点降下を示さなかった。また元素分析值もほとんど部算值と一 
表 1 Ia からの反応生成物 $\left\{\begin{array}{l}\mathrm{Ia}: 74.5 \mathrm{~g}(0.52 \mathrm{~mol}) \\ \text { DTBP : } 18.9 \mathrm{~g}(0.13 \mathrm{~mol})\end{array}\right\} 140 \sim 142 \mathrm{C}, 8$ 時間

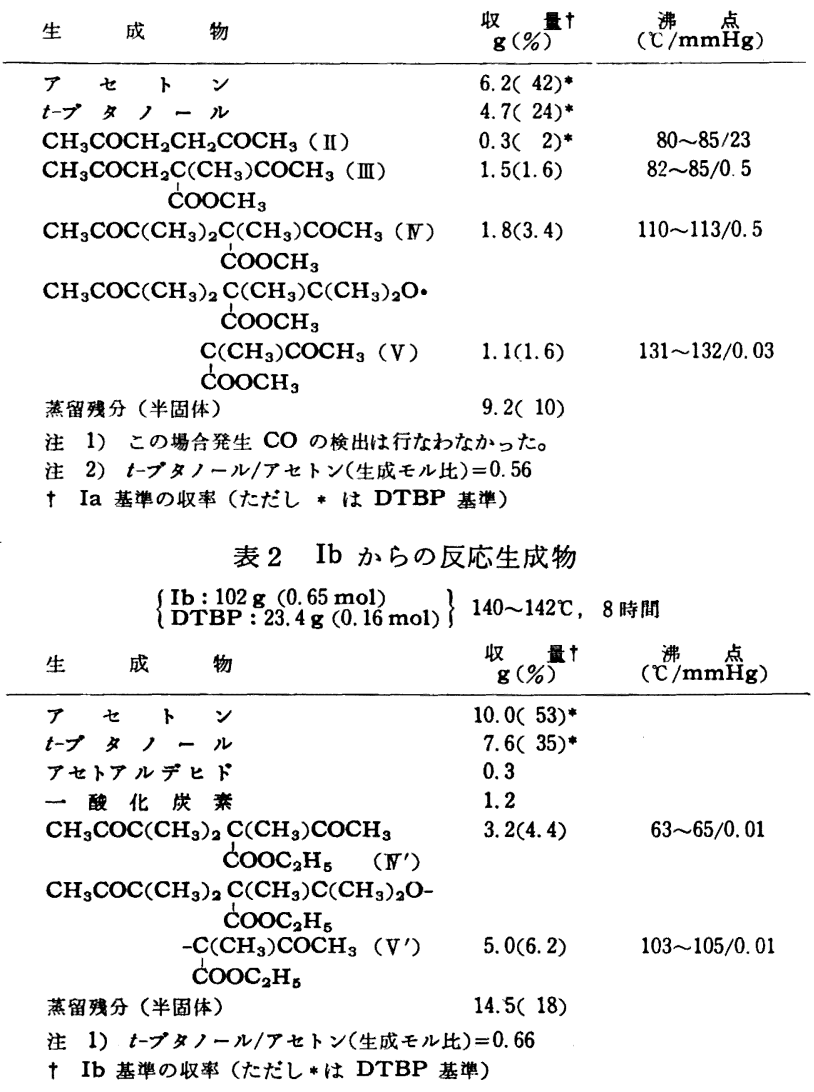

致した。III, $\mathrm{N}$ は蒸留によって単離した。それらの元素分析值お よび 2, 4-D の元素分析値はいずれも計算值とほぼ一致した。さ らにアセト酢酸メチルから標品を別途合成し，それらの IR 図抽 よび 2,4-D の IR 図が III，N のそれとよく一致することを認め た（図 1 参照）。

$\mathrm{CH}_{3} \mathrm{COCH}_{2} \mathrm{COOCH}_{3} \frac{\text { 1) } \mathrm{Na} \text { トルメン中 }}{2) \mathrm{CH}_{3} \mathrm{I}} \mathrm{CH}_{3} \mathrm{COCH}\left(\mathrm{CH}_{3}\right) \mathrm{COOCH}_{3}$ 1) $\underset{\mathrm{Na} \text { トルエン中 }}{\text { 2) } \mathrm{CH}_{3} \mathrm{COC}} \underset{(\mathrm{R})_{2} \mathrm{Br}}{\longrightarrow} \mathrm{CH}_{3} \mathrm{COC}(\mathrm{R})_{2} \mathrm{C}\left(\mathrm{CH}_{3}\right) \mathrm{COCH}_{3}$

な拈 Nの NMR スペクトル図 (図3参照) は明らかにメトキシ メチル，メチルケトンのメチル，他に三つのメチル基の存在をそ れぞれ $\tau=6.45,8.0,8.6,8.7,8.8$ の位置に示している。こ こでNの $\alpha, \alpha$-ジメチルアセトニル基の二つのメチル基が非等価 であることは，ある程度立体障害が存在して和り自由回転が妨げ

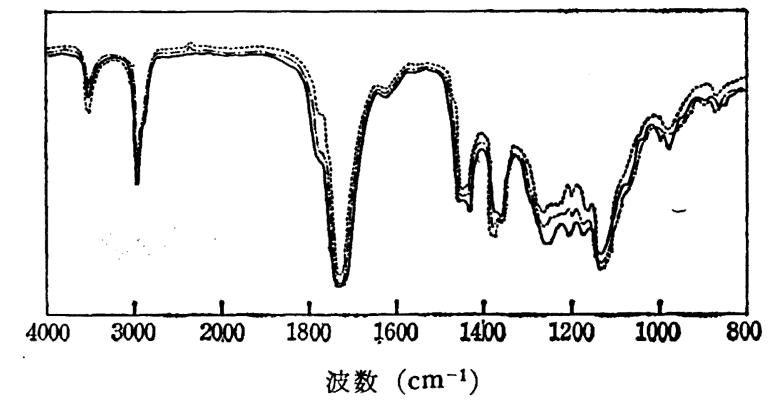

図 1 生成物 III, N, V の IR スペクトル —: III, -.-: N, - - : V

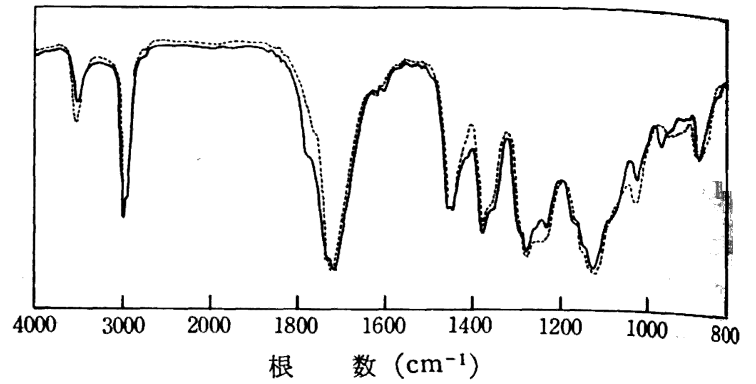

因 2 生成物 $\mathrm{N}^{\prime}, \mathrm{V}^{\prime}$ の IR スペクトル四 - $: N^{\prime}, \quad--: V^{\prime}$

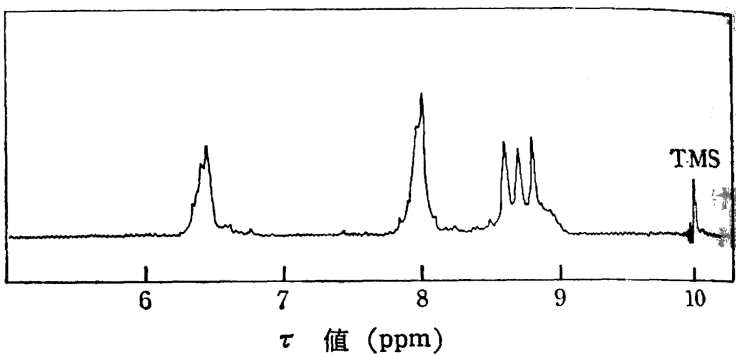

図 3 生成物 Nの NMR スペクトル図

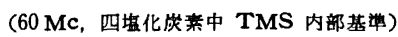

られているものと考えられる。つぎにVは高真空蒸留により単離 し，その元素分析值および IR 図（図1）よりNに類似の構造と 推定した。蒸留残分はベンゼンに溶かしてから石油エーテル可容 分と不溶分とに分別したが，いずれの IR 図す $\mathrm{N}, \mathrm{V}$ のそれと酷 似しており，同様の構造を有するオリゴマーと思われる。また ${ }^{\prime}$ け蒸留で単離した。 $\mathrm{N}$ と同様そのもの拈よび 2, 4-D の元素分桄 値はよく計算値と一致した。さらに標品をアセト酢酸エチルより 別途合成し，このものおよび 2,4-D の IR 図はいずれる $N^{\prime}$ か らのそれらと一致した。 $\mathrm{V}^{\prime}$ は高真空蒸留で単離し，元素分析值 は計算值とよく一致した。IR 図はV Vとれと極めて類似して捛 り $\mathrm{V}$ と同様な構造と考えられる。またベンゼン中皮点降下法で求 めた分子量の值 (379) は計算值 (386) とほぼ一致した。以上K おいて III の 2, 4-D の標品との混融試験では明確に同一物でぬる

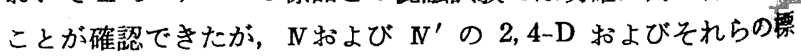
品の 2,4-D はいずれる融点幅が極めて広く，混融試験による碓 認を行ならことができなかった。

\section{3 論境}

以上の結果からつぎの四つの注目すべき点が見出される。

（i）エポキシ環への最初のラジカル攻撃は,アシルメチル望 ラジカルに限られる。

(ii ） グリシッド酸メチルェステルの反応ではアセトニルラジ カルの生成が認められるが，エチルエステルの反応ではこれが将 とんど羿められない。

(iii) アシルメチル型ラジカルとグリシット酸エステルの1 : 2 付加物括よびオリゴマーが単離され， $t$-ブトキシ型ラジカルの 攻撃による連鎖成長が僅かながら見られる。

(iv) アシルメシル型拉よび $\boldsymbol{t}$-ブチル型ラジカルの攻撃は っぱらェステル基のついた炭素上に起こっている。

つぎの各項でこれらの点を詳細に論ずることにする。 


\section{1 攻撃ラジカルの生成径路}

叫底系で最初に生成するラジカルはいうまでもなく DTBP の 些分解による $t$-ブトキシラジカルで，t-ブタノール生成の事実か 水素引抜き反応が起こっている筈で, 最す引抜かれ易いのはグ リシッド酸エステルのエステル基の $\boldsymbol{\alpha}$-水素と考えられる。環上 メチル基からの引抜きはこれに比して無視できよ5。しかもこの 水素引抜きはメチルェステルよりすエチルェステルの方が容易と 思われ，実際に生成 $t$-ブタノールの量も後者の方が大であった (表 1 , 表 2 参照)。

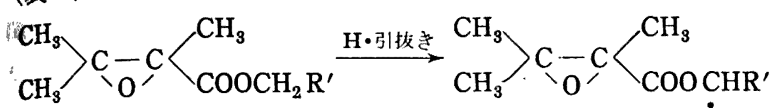

(Ia, Ib)

( $\mathrm{U}$ )

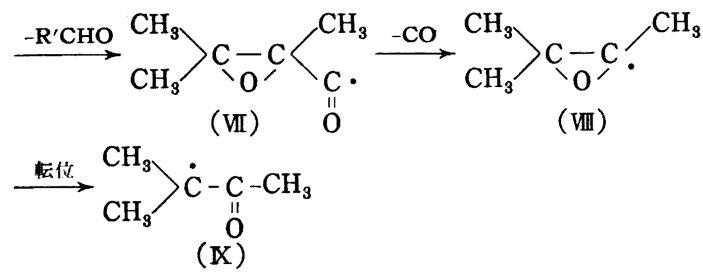

このようにして生成したエステルラジカル（U) は熱時に拈いて 脱アルデヒドを起こし，エポキシアシルラジカル(UI)を生成する と考兄られる。このアルデヒド脱離反応は，一般のエーテルのラ ジカル反応に招いて $\alpha$-水素が引抜かれ，つづいてアルキルラジ カルとカルボニル化合物へ分裂する反応に類似して扣り，この場 合はアシルラジカルの安定化も寄与していると考兄られる。な特 実際に Ib からのアセトアルデヒドは検出確認できたが，Ia から 生じている筈のホルムアルデヒドは量が少ないためかその生成を 確認できなかった。つぎに（VI）は一般のアシルラジカルと同様 飞熱時一酸化炭素の脱離を起こしてエポキシラジカル(UII)に変ず ると考えられ，Ib の場合についてその生成を確認した。環上に 笨素を持つエポキシドで水素引抜きが起こると，生成エポキシラ ジカルは熱時容易にアシルメチルラジカルに転位することは既に 今までの研究 ${ }^{2,3)}$ によって明らかで，上記エポキシラジカル（UII） 熱時容易に $\alpha, \alpha$-ジメチルアセトニルラジカル $(\mathbb{X})$ に転位する ると考えられる。単離された反応生成物 $\mathrm{N}, \mathrm{V}, \mathrm{N}^{\prime}, \mathrm{V}^{\prime}$ がいず れも分子の末端にこの構造を有していることは，明らかにこの ジカルの生成を示している。

エステル基からの水素引抜きがやや困難な Ia の反応では, DTBPから生じたアセトンで水素の引抜きが一部起こっているよ うで, アセトニルラジカル $\left(\mathrm{CH}_{3} \mathrm{COCH}_{2} \cdot\right)$ (X) の再結合体やこ の基を分子の末端に持つ化合物 (III) が単離されている。このラジ カル $(\mathrm{X})$ すアシルメチル型であるが，Xに比べるとその安定性は 劣り従って濃度る小さいと思われる。な拈 Ia と Ib の反応性の 善は反応物の合計収率にも反映されており，たとえば $\mathbf{N}+\mathrm{V} の$ 收率と $N^{\prime}+V^{\prime}$ の収率を比較した場合，たしかに前者の方がかな り小さい。

このょ5にして生成したアセトニル型ラジカル（X,X)は,そ の不対電子が $\alpha$-位のカルボニル基との共役によって共鳴安定化 していると考えられ，従ってその濃度も比較的大きく主たる攻撃 種となりらるのであろう。

\section{$3 \cdot 2$ ラジカルのエポキシ環攻俥}

生成物 III, $\mathbf{N}$ および $\mathbf{N}^{\prime}$ の構造が示す通り，これらの生成物は いずれすアシルメチル基と $\alpha$-メチルアセト酶酸エステル基とか
らできており，ラジカルがエポキシドの $\boldsymbol{\alpha}$-炭素を攻撃し付加開

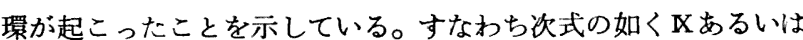
Xがエポキシ環を攻撃し，中間体として第三アルコキシラジカル （XI）が生成し，このものは水素引抜きで第三アルコールになる か, 熱時脱メチルを起こしケトン(XII)になって安定化することが 考えられる。<smiles>[R]OC(=O)C([R2])(C)[F+]C</smiles>

$(\mathrm{X}, \mathrm{X})$<smiles>[R]OC(=O)C([R])(C([R])(C)C)C(C)(C)[O-]</smiles>
(XI)<smiles>[R20]C(C)(C(=O)OC)C([R])(C)C([R])([R])C([R])(C)C([R])(C)C(C)(C)O</smiles>

実際に単離されたのはケトエステルでほとんどが脱メチルして ケトンになったようであるが，これらを粗留のままIR にかけた 場合 $-\mathrm{OH}$ の吸収がかなり見られることから，水素引抜きもある 程度起こっていることは確かなよ5である。

さらにこのアルコキシラジカルが単量体であるエポキシエステ ルへ繰返し付加することによって生じたと見なしうる Vあるいは $\mathrm{V}^{\prime}(1: 2$ 付加物) が単離されたこと, また蒸留不能の残渣（平 均重合度 4) の IR が Vや $\mathrm{V}^{\prime}$ とほとんど変りないことは, 低重 合度ながらすエポキシェステルのラジカル重合が起こっているこ とを示するのである。すでに著者らは2゙スチレンオキシドの重合 で同様のことを認め，アルコキシラジカルが連鎖生長過程に含ま れると脱水素, 不均斉化, 脱カルボニルなどが容易に起こるため に連鎖移動が激しく，高重合物が得られにくいことを指摘した。

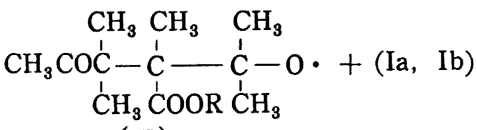

(XI)

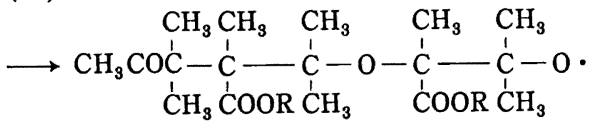

(XII)

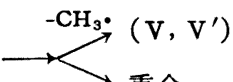

(Ia, Ib) 重合

ところで DTBP からの $t$-ブトキシラジカルが(XI) と同型のラ ジカルであるのに，これがエポキシェステルを攻撃した生成物は 全く単離されていない。このような差異について目下のところ十 分な説明は困難であるが, $t$-ブトキシラジカルでは 3 個のメチル 基があり，脱メチルに際し超共役による遷移状態の安定化が特に 大きく，Xにくらべてラジカルの寿命が短かいのではないかと考 えられる。

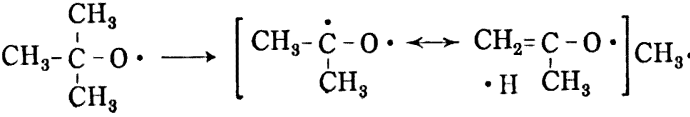

$$
\begin{aligned}
& \longrightarrow \mathrm{CH}_{3}-\mathrm{C}=\mathrm{O}
\end{aligned}
$$




\section{3·3 エポキシドの開環方向}

すでに述べたよらにェポキシェステルヘラジカルが付加する際, その攻撃位置が立体的に不利と思われるェステル基のついた $\alpha$ 炭素に限られるという事実は興味深いことである。一方著者ら” はさきにスチレンオキシド（SO）の DTBP 存在下での分解で フェナシルラジカルの付加が SO の $\alpha$-位にあかなり起こってい ることを認めた。一方 Gritter ら)の行なったプロピレンオキシ ド (PO) と DTBP の反応では、アセトニルラジカルの攻撃はも っぱらPO の末端炭素に起こっている。

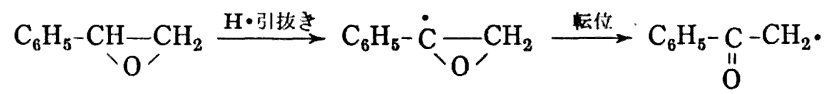

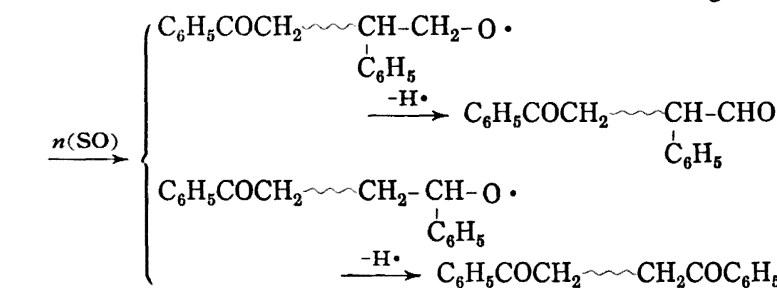

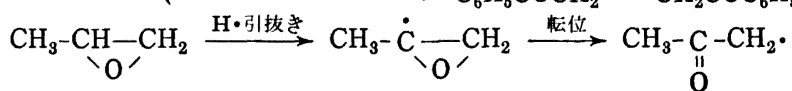

$$
\begin{aligned}
& \stackrel{\mathrm{PO}}{\longrightarrow} \mathrm{CH}_{3} \mathrm{COCH}_{2} \mathrm{CH}_{2} \mathrm{CHCH}_{\text {! }} \stackrel{+\mathrm{H} \cdot}{\longrightarrow} \mathrm{CH}_{3} \mathrm{COCH}_{2} \mathrm{CH}_{2} \underset{\text { O }}{\mathrm{CH}} \mathrm{CH}_{3}
\end{aligned}
$$

これらの結果より,フェニル基やェステル基のような共役性の 基が環炭素についている時は, 立体的には多少不利と思われるの にるかかわらず，その位置への攻撃がかなり有利になり，一方メ チル基のような非共役性（超共役の寄与はあってもフェニルなぞ に比べると極めて小さい）の基では，立体的に有利な末端炭素へ の攻撃が起こると考えられる。ところで生成したアルコキシラジ カルの共鳴安定化に対するこの共役性の基の寄与は構造上考元難 く, ラジカル付加の際, 要移状態に括いて共役性の基が共鳴安定 化に関与しているすのと思われる。<smiles>[R]OC(=O)[C@@]1([Y])OC1(C)C</smiles>

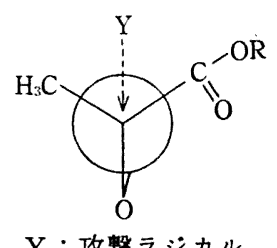

共役可能になるためには $\mathrm{O}, \mathrm{C}, \mathrm{Y}, \mathrm{C}=\mathrm{O}$ が同一平面内にあるこ とが必要で，Yは当然 O-C を延長した方向すなわちエポキシ酸 素の反対側から攻撃しなければならず， $S_{\mathrm{H}} 2$ 型でなければなら ない。

ところで共役基を持つェチレンへのメチルラジカルの付加が， 非置換のものに比べて異常に速く，この場合生成ラジカルの共鳴 安定化で説明されているが，エポキシドの場合は遷移状態に执い て共役性の基が寄与している点でやや異なり,その影響が Szwarc ら5)の提唱したメチル親和力の值と平行的であるか否かは, 今後 の詳しい検討に待たねばならない。

\section{4 実 験 の 部}

\section{$4 \cdot 1$ 原料エポキシェステル Ia, Ib の合成}

Darzens 反応により6) 合成した。すなわちアセトンと

6) R. Adams, Organic Reactions, Vol. 5, John Wiley \& Sons, Inc. N. Y. (1949) p. 413 ,
ルプロピオン酸エステルとをエーテル中ナトリウムアルコキシト と処理した。収率 $40 \sim 47 \%$ 。精留と乾燥とを繰り返し，最終的 には Iaは bp $74.0 \sim 74.5^{\circ} \mathrm{C} / 24 \mathrm{mmHg}$, Ib は bp 86.0 86. $5^{\circ} \mathrm{C} / 23$ $\mathrm{mmHg}$ の留分を得, このものを実験に用いた。これらはいずれる 気液クロマトグラフィーにより純粋単一物であることを確證し

\section{$4 \cdot 2$ 熱分解反応の装置}

反応器には還流冷却器, 窒素ガス吹込管, 温度計, 擤䢁器 置した通常の摺り合せ四つロフラスコを用いた。窒素ガスはFieser's solution, 䣫酸鉛, 硫酸, 塩化カルシウム, ペンゾフェノン の $\mathrm{Na}+\mathrm{K}$ ケチール溶液, ドライアイス浴に浸したトラップの首 で通じ精製したものを用いた。反応器からの流出ガスは先ずドラ イアイス泠却トラップを通したあと， $140^{\circ} \mathrm{C}$ に加熱した五酸化 ウ素管, 塩化カルシウム管, 硫酸, 炭酸ガス定量用カセイソー 管を通して放出した。

\subsection{Ia と DTBP の反応}

前記反応器中で $74.5 \mathrm{~g}(0.52 \mathrm{~mol})$ の Ia と $18.9 \mathrm{~g}(0.13 \mathrm{~mol})$ の DTBP とを混合し，室温で 30 分窒素ガスを通して置換した のち徐々に覮拌しつつ昇温し， $140 \sim 142^{\circ} \mathrm{C} て ゙ 8$ 時間加熱した。 反応液中に未反応 DTBP はすはや存在しないことを過酸化物唋 出テストで確認した。カセイソーダ粒管の重量增加は $0.53 \mathrm{~g}$ 。

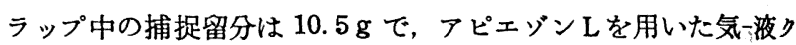
ロマトグラフィーにより,アセトン, $t$-ブタノール, DTBP (窒 素ガス流により未反応のまま運ばれたもの）の混合物であること を確認した。反応液はそのまま蒸留し, 低沸点留分, 高沸点留分, 蒸留残渣に分けた。低沸点留分からはアセトン, $t$-ブタノールの 混合物を得, トラップ中の留分と合一した。高沸点成分は減应 留により $60 \mathrm{~g}(80 \%)$ の原料エステル Iaを回収し,さらにII, II, $\mathrm{N}, \mathrm{V}$ を蒸留で単離した（データは表 1 参照）。残留残分 $9.2 \mathrm{~g}$ はベンゼンに容解させてから石油エーテルにて再沈殷精製し： 淡黄色粉末 $4.5 \mathrm{~g}$ を得た。なお III, N は，標品を次の方法で合 成し，混融，IR で同定を行なった。

$\boldsymbol{\alpha}, \boldsymbol{\beta}$-ジアセチル-a-メチルプロピオン酸メチル (III) : アセト 酢酸メチルより出発してヨウ化メチルでメチル化し, 次いでプロ ムアセトンでアセトニル化した。 $12 \mathrm{~g}(0.52 \mathrm{~mol})$ の $\mathrm{Na}$ を 400 $\mathrm{m} l$ のトルエンに分散し，穓拌しつつこれに $58 \mathrm{~g}(0.5 \mathrm{~mol})$ の アセト酢酸メチルを滴下し，モノナトリウム塩を調製した。これ に $20^{\circ} \mathrm{C}$ で $75 \mathrm{~g}(0.53 \mathrm{~mol})$ のヨウ化メチルを 30 分で滴下し, のち $20^{\circ} \mathrm{C}$ にて 3 時間, $70^{\circ} \mathrm{C}$ にて 5 時間加熱した。反応後口别 し, 蒸留して $\alpha$-メチルアセト酢酸メチル $39 \mathrm{~g}(60 \%)$ を得た。 bp $89 \sim 92^{\circ} \mathrm{C} / 45 \mathrm{mmHg}$ 。このうち $13 \mathrm{~g}(0.1 \mathrm{~mol})$ をトルェン中 で前と同様にナトリウム塩とし，これに $14 \mathrm{~g}(0.1 \mathrm{~mol})$ のブロ ムアセトンを 30 分, $20^{\circ} \mathrm{C}$ で滴下し, $20^{\circ} \mathrm{C}$ にて 2 時間, $70^{\circ} \mathrm{C} K$ て 3 時間加熱した。のち口別し蒸留して $3.0 \mathrm{~g}(17 \%)$ の III 得 た。bp $95 \sim 97^{\circ} \mathrm{C} / 5 \mathrm{mmHg}$ 。

$\boldsymbol{\alpha}, \boldsymbol{\beta}$-ジアセチル- $\boldsymbol{\alpha}$-メチルイソバレリアン酸メチル (IV) : $\alpha$ メチルアセト酢酸メチル $3.2 \mathrm{~g}(0.025 \mathrm{~mol})$ をトルェン中でナト リウム塩とし, これに $4.1 \mathrm{~g}(0.025 \mathrm{~mol})$ の 1 -アセチルイソフ ロピルブロミドを滴下し, $20^{\circ} \mathrm{C}$ にて 5 時間, $70^{\circ} \mathrm{C}$ にて 10 時間 加熱した。のち口別し蒸留して少量のNを得た。0.3 g(6\%), bp $83 \sim 85^{\circ} \mathrm{C} / 2 \mathrm{mmHg}$ 。

\section{$4 \cdot 4$ Ib と DTBP の反応}

$102 \mathrm{~g}(0.65 \mathrm{~mol})$ の Ib と $23.4 \mathrm{~g}(0.16 \mathrm{~mol})$ の DTBP とを 
$4 \cdot 3$ の場合と全く同じ条件扣よび操作法で反応させた。カセイン 一ダ粒管の重量增加は $2.0 \mathrm{~g}$ トラップ中の捕捉留分は $15.5 \mathrm{~g}$ で, 気一夜クロマトグラフィーにより，アセトアルデヒド，アセトン， tーブタノール，DTBP の混合物であることを確認した。一方反応 湖はそのまま蒸留し，低沸点留分のアセトン, $t$-ブタノールはト ラップ中のるのと合一した。高沸点留分は隇圧蒸留により $75 \mathrm{~g}$ (74\%)の原料エステルを回収したあと， $\mathrm{N}^{\prime} 、 \mathrm{~V}^{\prime}$ を蒸留で単離し た (データは表 2 参照)。蒸留残渣 $14.5 \mathrm{~g}$ はベンゼンに溶かして から石油エーテルにて再沈殿精製し, 分子量 658 (ベンゼン溶液 の水点降下法による）のものを $6 \mathrm{~g}$ 得た。な拉 $\mathrm{N}^{\prime}$ の標品を次の 方法で合成し，IR で同定を行なった。

$\boldsymbol{\alpha}, \boldsymbol{\beta}$-ジアセチル-a-メチルイソパレリアン酸エチル $\left(\mathrm{IV}^{\prime}\right): 26 \mathrm{~g}$ $(0.2 \mathrm{~mol})$ のアセト酢酸エチルより， N 標品合成と同様な操作 法で $\alpha$-メチルアセト酢酸エチルを合成した。収量 $17 \mathrm{~g}(60 \%)$,
表 3 元素分析値（カッコ内は計算値）

\begin{tabular}{|c|c|c|c|}
\hline 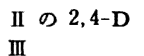 & $\begin{array}{l}\text { C } 46.32(45.57) \text {, } \\
\text { C } 58.47(58.05)\end{array}$ & $\begin{array}{l}\text { H } 4.45(3.82) \text {, } \\
\text { H } 8.08(7.58)\end{array}$ & N 23.63(23.62) \\
\hline III の 2,4-D & C $46.91(46.15)$, & H 4. 46(4.06), & N $20.73(20.51)$ \\
\hline N & C $60.84(61.66)$, & H $8.91(8.47)$ & \\
\hline $\begin{array}{l}\mathrm{N} \text { の 2,4-D } \\
\mathrm{V}\end{array}$ & $\begin{array}{l}\text { C } 47.29(48.08) \text {, } \\
\text { C } 60.58(60.31) \text {, }\end{array}$ & $\begin{array}{l}\text { H } 4.49(4.56) \text {, } \\
\text { H } 8.10(8.44)\end{array}$ & N 20.02(19.5 \\
\hline $\mathbb{N}^{\prime}$ & C $63.15(63.13)$, & H $9.10(8.83)$ & \\
\hline $\begin{array}{l}\mathbf{N}^{\prime} \text { の } 2 \\
\mathbf{V}^{\prime}\end{array}$ & $\begin{array}{l}\text { C } 49.11(48.98) \text {, } \\
\text { C } 62.15(62.00) \text {, }\end{array}$ & $\begin{array}{l}\text { H } 4.96(4.80) \text {, } \\
\text { H } 8.87(9.10)\end{array}$ & 4) \\
\hline
\end{tabular}

bp $91.5 \sim 92.0^{\circ} \mathrm{C} / 34 \mathrm{mmHg}$ 。つぎにこれを $4.3 \mathrm{~g}(0.03 \mathrm{~mol})$ と りそのナトリウム塩を調製してから $5 \mathrm{~g}(0.03 \mathrm{~mol})$ のアセチル イソプロピルブロミドを加え, 反応させてから蒸留により $N^{\prime}$ を $0.3 \mathrm{~g}(5 \%)$ 得た。bp $92 \sim 93^{\circ} \mathrm{C} / 2 \mathrm{mmHg}$ 。

(1964 年 10 月 19 日、第 15 回有機反応機構討論会講演)

\section{アイソタクチックポリブテン-1 の結晶変龍と捕捉ラジカルの挙動†}

(昭 和 40 年 1 月 16 日 受理)

楠本 直*. 福田建二**. 河野岩造**. 高柳素夫***

アイソタクチックポリブテン-1 の溶融結晶化試料 2 種 (Nattal) の結晶変態, Mod. I おょび Mod. II), 溶液結晶化 試料 (Mod. III) および急冷試料（ほほ無定形）について $-196^{\circ} \mathrm{C}$ 真空中で $\gamma$ 線を照射したのち ESR 測定を行なった。 ラジカルの反応性と分子運動との関連を調べるため, NMR および動的粘弾性の測定も同時に行なった。一 $120^{\circ} \mathrm{C}$ 以下の ESR スペクトルはすべてはやけた 6 本構造を含んでいるが, $-70^{\circ} \mathrm{C}$ 以上では 8 重項スペクトルを示す Mod. I, II のグ ループと，4重項スペクトルを示す Mod. III および無定形試料のクループに分かれる。一方， $-196^{\circ} \mathrm{C}$ から順次年温し たときのラジカル量の変化を測定すると，各温度でラジカルの比残存量は常に Mod. I >Mod. III >無定形の順であった。 ラジカルの減少は $-120^{\circ} \mathrm{C}$ 付近からゆっくり始まり, $-50^{\circ} \mathrm{C}$ から $-30^{\circ} \mathrm{C}$ 付近で急になり, 無定形試料では $-20^{\circ} \mathrm{C}$, Mod. III の試料では $-10^{\circ} \mathrm{C}$ 付近でラジカルが消减する。Mod. I の試料は $70^{\circ} \mathrm{C}$ 付近で, 8 重項を示すラジカルが消減 する。

Mod. I および無定形試料では, $-35^{\circ} \mathrm{C}$ のガラス転移温度と $-80^{\circ} \mathrm{C}$ とに非晶領域の局所的な分子運動に基つく $\mathrm{NMR}$ 吸収線幅の狭化があり,さらに $-180^{\circ} \mathrm{C}$ 以下に側鎖の運動に基つく狭化が認められた。粘弾性測定の結果にもこれらの狭 化に対応する分散領域を認めた。ガラス転移温度での分子運動はラジカルの急速な消隇を招く。一方，ガラス転移温度以 下の領域では，局所的な分子運動はラシシカルの消滅に直接関係しないと推論した。

\section{1 楮言}

アイソタクチックポリブテン-1 は, 他のいくつかのポリ $\alpha-オ$ レフィン類にも見られると同様にその側鎖の配位，あるいは分子 鎖ラセンの方向性などに基つくくと思われる三つの結晶変態)を持 っている。これらの結晶変態は, その物性を種々の面から比較検 討するときには, 一面に打いて結晶構造と分子鎖の熱運動性,さ らにいいかえれば分子間相互作用に関する知見を得るために有用 な材料となるだろう。著者らは，すでにアイソタクチックポリブ テンー1 の最も安定な結晶変態) (Modification I) と無定形物と

† 本報告を「ボリオレフィンの磁気共鳴に関する研究（第 2 報)」とする。

* Naoshi KUSUMOTO 九州大学工学部原子核工学教室 : 福 岡市箱崎町.

** Kenzi HUKUDA, Iwazo KAWANO 九州大学教養部物理 学教室: 福岡市大坪町.

*** Motowo TAKAYANAGI 九州大学工学部応用化学教室 : 福岡市箱崎町.

1) G. Natta, Makromol. Chem. 65़, 139 (1963).
について， 線照射したときに捕捉されるラジカル種が熱処理に よってそれぞれ全く異なったものに変るという ESR の観測結果 を報告した ${ }^{2)}$ 。ここではさらに溶融物を高温で結晶化して得られ る準安定な結晶変態 (Modification II)，および溶液から結晶化 して得られる結晶変態 (Modification III) について検討を加えた 結果を報告する。この際, ラジカルの反応性は分子鎖の熱運動と す密接な関係を持っていることから,ブロードライン NMR と動 的粘弾性を測定し, ラジカル挙動を分子運動性の面からる併せて 検討することにした。

\section{2 実 験 方 法}

\section{$2 \cdot 1$ 試 料}

試料（a ）扣よび (d)は (Petro-tex, Petro-tex 社製アイン タクチックポリブテン-1）からすでに報告した方法2)により作成 したもので（a）は最も安定した結晶変態（Mod. I）を含も部 分結晶化試料，(d)はほぼ無定形と見なされる急冷試料である。

2) 福田, 楠本, 河野, 高柳, 工化 67, 2163 (1963). 